\title{
コンクリート構造物の耐久設計指針（試案）
}

\section{PROPOSED RECOMMENDATION ON DURABILITY DESIGN FOR CONCRETE STRUCTURES}

\author{
耐久性設計小委員会 \\ By Subcommittee on Durability Design for Concrete Structures, JSCE
}

\section{1. 試案作成の経緯}

耐久性を特に考慮したコンクリート構造物の体系的な 設計手法の確立を目指して, 土木学会コンクリート委員 会では, 昭和 63 年 1 月に耐久性設計小委員会（委員長 : 岡村 甫 東京大学教授) を設置して, 耐久設計の指 針を作成するための活動を行ってきた．上記小委員会で は, 各分野を代表する委員の活発な討議を経て, 耐久設 計の統一概念，耐久性に対する検討方法ならびに具体的 な環境指数と耐久指数の提示など，耐久設計指針の骨格 をとりまとめた.

環境指数や耐久指数の細部については, 今後亡も検討 すべき余地は残されていると思われる．しかしながら， 耐久設計指針 (試案) として公表し, 各種のコンクリー 卜構造物に適用して頂き，その場合に生ずる疑問点や問 題点の提示を受けることは, 今後のコンクリート構造物 の耐久設計指針の制定において重要かつ不可欠なことで ある. そのため, 昭和 63 年 12 年に解散した小委員会の 成果を, 土木学会コンクリートライブラリー第 65 号と して, 平成元年 8 月に公表した. また，同年 8 月 30 日 には，この試案をテキストにした「コンクリート構造物 の耐久設計の新しい考え方」の講習会が開催された.

\section{2. 目次}

コンクリート構造物の耐久設計指針（試案）は，下記 のように 5 章の構成となっている. また付録として, 試 案作成までの経緯と下記の試設計例を揭載し, 試案の理 解および普及の一助としている.

1 章 総 則

2 章 耐久性に対する検討

\author{
3 章 環 境 指 数 \\ 4 章 耐久指数 \\ 5 章 耐久性ポイント \\ 付録-1 $\mathrm{RC}$ 橋脚の設計例 \\ 付録-2 3 径間連続 PRC 2 主版析橋の設計例 \\ 付録-3 各種コンクリート構造物の設計例
}

\section{3. 適用の範囲}

本試案における耐久設計では，新たに建造されるコン クリート構造物を対象としている. したがって, 既設構 造物の補修あるいは補強のための耐久性診断あるいは残 存寿命予測を対象亡はしない.

\section{4. 検討の方法}

コンクリート構造物の耐久性に対する検討は, 部材各 部において, 耐久指数 $T_{p}$ が環境指数 $S_{p}$ 以上であるこ とを確かめることにより行う.

$T_{p} \geqq S_{p}$

式（1）に示された考え方は，新しい概念であるが, 安全性に対する検討の考え方と基本的には同じである. 部材各部の耐久性を照査するということは, 安全性に対 する検討と同様に，耐久性が最も低下するおそれがある 断面各部をすべて照査するということを意味している. すべての検討箇所において耐久性照査に合格すれば，構 造物は耐久的であると判定されるのである.

本試案では, 耐久性に対する検討は, 構造物の設計段 階で，材料および施工についての実際の様態を想定して 行うものとしている.この段階で式（1）が満足されな い場合には, 構造物の施工を開始するまでに, 設計, 材 料および施工についての再検討が必要となる. 


\section{5. 環 境指 数}

環境指数 $S_{p}$ は, 構造物が置かれる環境条件および要 求されるメンテナンスフリーの期間を考慮して定めるも のとし，一般に式（2）により算定される.

$S_{p}=S_{0}+\sum\left(\Delta S_{p}\right)$

ここに， $S_{0}$ は標準的な環境条件における環境指数值を 示し, 50 年間メンテナンスフリーのコンクリート構造 物を建造する場合に 100 とする。ここで，メンテナンス フリーとは, 目視観察等によって耐久的であると判断で き,補修あるいは補強をしなくてよい状態のことである.

環境指数值 $S_{0}$ を 100 と設定すると著しく不経済とな る場合，あるいは逆に，100以上に設定した方が総合的 にみれば経済的となる場合もある.このような場合には， メンテナンスフリーの期間をそれぞれ短くあるいは長く 設定する. なお，標準的な環境条件において，メンテナ ンスフリーの期間を 10〜 15 年程度とする場合の環境指 数值 $S_{0}$ は 0 程度と想定している.

式 ( 2 ) の $\Delta S_{p}$ は, 塩分や凍結融解作用の影響が厳 しい環境条件における環境指数の増分値であり, 一般に 表一1の值が用いられる. また，これらの環境条件が組 み合わされる場合には, 増分値 $\Delta S_{p}$ を累加する.

表一1に示す環境指数の増分値 $\Delta S_{p}$ が確定値でなく, 範囲として与えられているのは，塩分の影響は構造物が 設置される地域, 地形, 海岸線からの距離, および気象・ 海象条件等の影響を受け, 一義的に定めることが困難で あること, また凍結融解作用の影響も地域による変化が 著しいことによる. 個々の構造物においては, 設置場所 の環境条件の具体的, 地域的な特性を考慮して増分值 $\Delta S_{p}$ を定めていく必要がある.

コンクリート構造物の耐久性を損なう環境条件として は, 表一1 に示すもののほか, 特殊な土壌や温泉地帯の ような腐食性環境等が考えられる.このように環境条件 がきわめて厳しく, かつ特殊な場合には, 具体的な個々 の状況に応じて, 別途詳細な検討を行う必要がある. 道 路橋の床版等のように疲労の影響が，環境条件による影 響亡重なる場合は, 耐久性劣化のメカニズムが複雑であ り, その程度を定量的に予測することが困難である.し たがって, この種の問題については, 今後の研究に待つ こととし, 本試案では取り上げていない. また, アルカ リ骨材反応による劣化は, 構造物建造前の段階において 十分に対処できるので, 環境指数の増分值には加えてい

\section{表一1 環境指数の増分値 $\Delta S_{p}$}

\begin{tabular}{c|c}
\hline 環 境 条 件 & $\Delta S_{p}$ \\
\hline 塩分の影響が大きい & $10 \sim 70$ \\
\hline 凍結融解作用が著しい & $10 \sim 40$ \\
\hline
\end{tabular}

ない.

\section{6. 耐久指数および耐久性ポイント}

耐久指数 $T_{p}$ は, コンクリート材料の品質, コンクリー トおよび補強材の品質, 設計ひびわれ, 部材の形状・鉄 筋詳細・設計図，コンクリート工，鉄筋工・型枠・支保 工のほか，PC工に関する補足事項，さらに防護工等を 考慮して定めるものとし, 一般に式（3）により算定さ れる.

$$
T_{p}=50+\sum T_{p}(I, J)
$$

ここに, $T_{p}(I, J)$ は, 構造物の耐久性に関係する要因 の影響を定量的に評価した耐久性ポイントであり，表一 2 に示す項目に分けて，規定されている.

\section{表一2 耐久性ポイント $T_{p}(I, J)$ の算定項目}

\begin{tabular}{|c|c|c|c|}
\hline$I$ & $J$ & 項 & $T_{p}(I, J)$ \\
\hline \multirow[b]{2}{*}{1} & \multicolumn{3}{|c|}{ 【コンクリート材料】 } \\
\hline & $\begin{array}{l}1 \\
2 \\
3 \\
4\end{array}$ & $\begin{array}{l}\text { セメント } \\
\text { 骨材の吸水率 } \\
\text { 骨材の粒度 } \\
\text { 混和材料 }\end{array}$ & $\begin{array}{l}10 \sim 0 \\
8 \sim-10 \\
0 \sim-5 \\
20 \sim-15\end{array}$ \\
\hline \multirow[b]{2}{*}{2} & \multicolumn{3}{|c|}{ 【コンクリートおよび補強材】 } \\
\hline & $\begin{array}{l}1 \\
2 \\
3 \\
4 \\
5 \\
6\end{array}$ & $\begin{array}{l}\text { ワーカビリチー } \\
\text { 堅硬性 } \\
\text { 単位水量 } \\
\text { 塩化物含有量 } \\
\text { コンクリート製造工場の管理状態 } \\
\text { 防錆した補強材 }\end{array}$ & $\begin{array}{c}35 \sim-30 \\
20 \sim-15 \\
10 \sim-25 \\
5 \sim-30 \\
10 \sim-10 \\
T_{p}(4,2) \text { を修正 }\end{array}$ \\
\hline \multirow[b]{2}{*}{3} & \multicolumn{3}{|c|}{ 【設計ひびわれ】 } \\
\hline & $\begin{array}{l}1 \\
2\end{array}$ & $\begin{array}{l}\text { 温度ひびわれ指数 } \\
\text { 曲げひびわれ幅 }\end{array}$ & $\begin{array}{l}10 \sim-20 \\
10 \sim-20\end{array}$ \\
\hline \multirow[b]{2}{*}{4} & \multicolumn{3}{|c|}{ 【部材の形状・鉄筋詳細・設計図】 } \\
\hline & $\begin{array}{l}1 \\
2 \\
3 \\
4 \\
5 \\
6\end{array}$ & $\begin{array}{l}\text { 部材の形状・寸法 } \\
\text { かぶり } \\
\text { 鉄筋の段数およびあき } \\
\text { 用心鉄筋 } \\
\text { 打継目 } \\
\text { 設計図 }\end{array}$ & $\begin{array}{c}T_{p}(2,1) \text { で考慮 } \\
30 \sim-30 \\
15 \sim-35 \\
10 \sim 0 \\
0 \sim-25 \\
0 \sim-30\end{array}$ \\
\hline \multirow[b]{2}{*}{5} & \multicolumn{3}{|c|}{ 【コンクリート工】 } \\
\hline & $\begin{array}{l}1 \\
2 \\
3 \\
4 \\
5\end{array}$ & $\begin{array}{l}\text { 主任技術者 } \\
\text { 受入れ } \\
\text { 運搬・打込み・締固め } \\
\text { 表面仕上げ・湌生 } \\
\text { 打継目の施工 }\end{array}$ & $\begin{array}{c}20 \sim-5 \\
5 \sim-5 \\
20 \sim-45 \\
5 \sim-40 \\
T_{p}(4,5) \text { を修正 }\end{array}$ \\
\hline \multirow[b]{2}{*}{6} & \multicolumn{3}{|c|}{ 【鉄筋工・型枠・支保工】 } \\
\hline & $\begin{array}{l}1 \\
2 \\
3 \\
4\end{array}$ & $\begin{array}{l}\text { 鉄筋加工 } \\
\text { 鉄筋の組立て } \\
\text { 型枠 } \\
\text { 支保工 }\end{array}$ & $\begin{array}{c}5 \sim 0 \\
5 \sim-20 \\
20 \sim-15 \\
5 \sim-5\end{array}$ \\
\hline \multirow[b]{2}{*}{7} & \multicolumn{3}{|c|}{ 【PC 工の補足事項】 } \\
\hline & $\begin{array}{l}1 \\
2 \\
3 \\
4\end{array}$ & $\begin{array}{l}\text { 技術者の経験・資格 } \\
\text { グラウトの材質 } \\
\text { 後埋めコンクリートの品質 } \\
\text { グラウトの施工方法 }\end{array}$ & $\begin{array}{l}0 \sim-5 \\
5 \sim 0 \\
0 \sim-5 \\
0 \sim-5\end{array}$ \\
\hline \multirow{2}{*}{8} & \multicolumn{3}{|c|}{ 【防護工】 } \\
\hline & 1 & 表面防護工 & $20 \sim 0$ \\
\hline
\end{tabular}


耐久指数 $T_{p}$ は, コンクリート構造物の耐久性に影響 を与える要因を材料・設計・施工の各分野別に細かく分 割して, そのおのおのを定量的に評価した耐久性の総合 点として算定される. 環境指数 $S_{p}$ には, 構造物が設置 される環境条件に対応し, 塩分や凍結融解作用の程度に 応じた増分值 $\Delta S_{p}$ が定められているが，耐久指数 $T_{p}$ は式（3）のように一義的に規定されている. 耐久指数 の場合も，異なった環境条件に対応して，個々の要因の 影響度を変化させることはもちろん考えられるが，その 影響の相違を厳密に区別することは困難である。また， 耐久指数は多岐にわたる要因の評価点を合計して得られ るものであり, 耐久指数の高い構造物は総合的にみて優 れたものであると考えられる. 以上のことを考慮し，耐 久指数を一義的に規定している.

耐久性ポイント $T_{p}(I, J)$ は，表一2 に示すように， コンクリート構造物の耐久性に影響を及ぼす項目を 8 種 類に大別し $(I=1 \sim 8)$, さらにその個々の項目を $1 \sim 6$ 個 $(J=1 \sim 6)$ の小項目に分割している. そして，各小 項目ごとに，おのおのその影響を定量的に評価したもの が示されている.
各小項目は，それぞれ完全に独立したものではなく， 本来相互に関連するものであり，分割して取り扱うべき 性質のものではない。しかしながら，簡単さを主眼に， 分離独立して表示することを原則としている.このため, 各小項目の影響を二重に考慮しないように十分に配慮し てある．ただし，完全に分割して表示することが困難な 一部の小項目については, 相互に関連付けて示している. 耐久指数および耐久性ポイントを定めるにあたり，耐 久性に影響を及ぼす数多くの要因をそれぞれ評価し，さ らに定量的に示すことが困難であったことはいうまでも ない. とりわけ，施工に関する要因をどのように定量的 に取り扱うかが最も難しい点であった．施工の影響は人 的要因が大きいため, 定量化しにくいのである.しかし ながら，コンクリート構造物の耐久性を改善し，コンク リート構造物に対する信頼性を高めることは急務であ る. したがって, データの裏付けの少ないものであって も，早急に役立つことを目指して，耐久性ポイント $T_{p}$ $(I, J)$ を規定している. 今後の研究によって, 改善さ れていくことを期待している.

（文責：岡村 甫・辻 幸和 $/ 1989.12 .22$ ・受付） 